\title{
Russia's return to the superpower status
}

\author{
Mirosław Minkina ${ }^{1^{*}}$ \\ ${ }^{1}$ Siedlce University of Natural Sciences and Humanities, Faculty of Humanities, Siedlce, Poland
}

\begin{abstract}
OBJECTIVES: The elite of Russian power and Russian society have never come to terms with the collapse of the Soviet Union. They also did not accept ta world order with the United States in the primary role. The purpose of this article is to examine the policy of the Russian Federation, which is aimed at rebuilding its superpower position, and to identify the reasons that clearly define Russia’s determination in this respect.

METHODS: Achieving the formulated goal will be possible by answering the question: Why does Russia strive to rebuild its status of global superpower and what actions does it undertake as part of its policy? This question is the main research problem, taken up by the authors. In order to solve the indicated problem, theoretical methods will be used in the form of: source and literature criticism, analysis, synthesis and inference.

RESULTS: Nobody denies that Russia is still one of the largest countries in the world. Nonetheless, it is much smaller and weaker than the USSR. By means of assertive, not to say aggressive and anti-western politics it demands to be recognised as a superpower eligible to decide on the international order. However, in the contemporary world, superpower status is to a much smaller extent decided by territory.
\end{abstract}

CONCLUSIONS: The foundations of the Russian superpower status are weak, and the popular anti-western narrative is not conducive to strengthening the Kremlin's position internationally.

Keywords: superpower, change, foreign and security policy, Russian Federation

* Corresponding author: miroslaw.minkina@uph.edu.pl

OPEN () ACCESS (C) (i) ()

This work is licensed under the Creative Commons Attribution-NonCommercial-NoDerivatives 4.0 License. 


\section{Introduction}

After the collapse of the USSR in 1991, Russia, its successor, was almost 1/4 smaller, and the population of the Russian Federation was reduced by almost 150 million compared to the demographic resources of the USSR. Along with the demise of the USSR in 1991, Russia lost almost one fourth of its territory (The World Factbook 2016a) ${ }^{1}$ and almost 150 million citizens (The World Factbook 2016b) ${ }^{2}$. For comparison - the territory of the European Union is more than 4 million $\mathrm{km}^{2}$ in total, and has a population of 508 million (European Union 2016). At the end of the 1980s and the beginning of the 1990s, the states of Central and Eastern Europe rejected the totalitarian communist regime and started to seek their new place in the new geopolitical reality. In Russia, the structural transformation was tedious and exhaustive. The breakup of the Soviet empire was a more complicated process, conditioned by the internal and external situation stemming from the international and legal position of the USSR in the world. The decline of the state took the elites by surprise, they felt helpless and lost. For these were the elites who had set the ideological tone of the empire and implemented the communist party's policy in society and the economy. Unlike the elites in Central and Eastern Europe, and the Baltic States, who were in favour of integration with the Euro-Atlantic structures, the Russian elites experienced a lack of ideological orientation. The only idea that came to their minds was to strengthen the state in all spheres of its functioning and restore its position in the world. Such a way of thinking was strengthened by the financial crisis in 1998 and Russia's humiliation during the conflict in Kosovo.

There is a strong historical cult of statehood in Russia. Thus, at the beginning of the $21^{\text {st }}$ century, the concept of creating strong state capitalism gained popularity, with the energy sector and industrial-munitions complex as its core. The energy sector was to elevate the state to the position of an energy superpower (Orłow 2006), while new technologies were to become part of the national economy and to enable the creation of a strong army, capable, if necessary, of supporting the international policy. The influence of the defence industry on the economy is always present in Putin's thinking. At the International Military-Technical Forum in 2015, he emphasised that 'thanks to the implementation of the state armaments programme, the share of up-to-date armaments

1 The area of the USSR was $22,402,200 \mathrm{~km}^{2}$ in total, the surface of Russia (without the Crimea) is $17,098,242 \mathrm{~km}^{2}$.

2 The population of the USSR was 293,047,571, and the population of Russia is 142,355,415. 
will reach a level of $70 \%$, and in some cases even $100 \%$ by the year 2020 . This is a very ambitious plan. We anticipate that the infrastructure of the defence industry, research and design centres will spare no effort to implement the plans in due time and ensure high quality. Of course, the effective munitions industry is vital for the growth of the whole economy. What is more, this is the munitions industry that should set the technological and production standards and remain the driving force for the development of double use innovations to be used in such branches of the economy as: energy sector, communications, microelectronics, and others. It is important to improve the mechanism of private and public partnership in those sectors, disseminate positive experience of private entities offering parts and componentry for military production, and increase the participation of civilian companies, universities, research centres in the implementation of state defence orders (Speech at the ceremony... 2015).

The purpose of this article is to examine the policy of the Russian Federation, which is aimed at rebuilding the superpower position of this state, and to identify the reasons that clearly define Russia's determination in this respect.

For the needs of this study, the following definition given by Alice Lyman Miller was adopted: "superpower" is a country that has the capacity to project dominating power and influence anywhere in the world and sometimes in more than one region of the globe at a time, and so may plausibly attain the status of global hegemon (Lyman Miller 2005).

Achieving the formulated goal will be possible by answering the question: Why does Russia strive to rebuild its status of a global superpower and what actions does it undertake in its policy? This question is the main research topic to be taken up by the author.

\section{The Visions of Russian Policy after the Demise of the USSR}

In the foreign policy of the Russian Federation (RF) after the demise of the USSR, two constantly present and interweaving tendencies can be distinguished. The first one results from the assumption that the contemporary world is unipolar, with the US in the leading role. In such a situation, Russia should be as close as possible to the centre and part of the American-Russian duet deciding about the international order. Such 
thinking was dominant at the time of the so-called honeymoon in relations with the West during Yeltsin's presidency. Such an attitude was also convincing for Vladimir Putin at the beginning of his first term of office. His first ally was to be Tony Blair, with whom the Russian president intended to build friendly relations. Putin also believed that it was possible to have very good relations with the West, and especially with the USA. At the same time, he knew that the West did not understand Russian specificity, although he did not perceive it as an obstacle. He believed that it was necessary to meet, convince and explain the position of Russia and its problems. At that time, Putin accepted visits from every western leader and every minister of foreign affairs. He devoted more time to them than the protocol, and sometimes more than was common sense (Zygar 2016, p. 24). He adopted a similar attitude when the anti-terrorist coalition was being established after the 11 September attacks in 2001. Vladimir Putin was the first to declare support for the American effort in the fight against the terrorist threat by emphasising the availability of all the forces and materiel at the disposal of Russia. "General Karabilnikov's, the Chief of the GRU (the Main Intelligence Directorate), visit to Washington in February 2002 was a confirmation of this commitment. During the visit, several important meetings were held, inter alia, with the Chief of the Joint Staff, General Richard B. Myers, as well as the director of the Defense Intelligence Agency, Vice-Admiral Thomas R. Wilson. During the meetings, the rules for cooperation in terms of military intelligence in the fight against terrorism were discussed. "In order to convince the Americans about Russia's true intentions, the Chief of the GRU revealed some information vital for combating terrorism. The will to cooperate with the USA and the West was also visible during the presidency of Dmitry Medvedev who expressed the need for ta partnership for modernisation" (Gertz and Scarborough 2002).

Representatives of a different strand in foreign policy claim that the essence of the contemporary world is its multipolar character and Russia should play the role of an important centre in this configuration. "According to some representatives of this strand, the concept of 'multipolar world' should be used as a bargaining chip in relations with the West in order to obtain a more important position in a de facto unipolar world. Others, on the other hand, believe that the international reality is truly multipolar" (Khudoley 2016, pp. 389-390). The latter opinion started to prevail in the mid-1990s, when Yevgeny Primakov became the minister of foreign affairs, prior to which he was the director of the Foreign Intelligence Service of the RF. At that time, a shift in the philosophy of thinking about foreign policy took place. Two days after entering his ministerial office, in January 1996, he organised a press conference during which he 
announced that he was taking office as 'a necessity to intensify the activity of the Ministry of Foreign Affairs in the defence of the Russian national and state interests' (Mleczin 2011, p. 1191). In May 1998, Boris Yeltsin visited the ministry of foreign affairs. In his speech, he supported Primakov's activity, saying that 'our diplomacy is taking a breath of fresh air, it is becoming more active, it is getting more principled and more skilful in attaining its goals. Russian foreign policy is currently enjoying great authority in the world, they reckon with us. I can guarantee, that I will do my best to enhance and assure the utmost professionalism of the staff of the Ministry of Foreign Affairs' (Mleczin 2011, p.1198).

This was probably the first time that the president said that the world should be multipolar. He also asked for appreciation of the presidential diplomacy carried out without neckties, and ascertained - using an erotic comparison - that Russia did not lie under the United States (Mleczin 2011, p. 1198).

It seems that the shift was in line with Russia's foregoing approach to foreign policy. For almost half a millennium, it was characterised by constant expansion which started during Ivan the Terrible's reign. It was calculated that until the era of the USSR, the territory was enlarged by about $80 \mathrm{~km}^{2}$ a day on average to cover over $1 / 6$ of the globe. At the beginning of the $20^{\text {th }}$ century, Russia was the fifth industrial power and the largest producer of agricultural produce in Europe. But at the same time, its GDP amounted to $20 \%$ of Great Britain's and 40\% of Germany's GDP (Kotkin 2016, pp. 2-3).

Several vital events decided the advantage and power of Russia. One of them was the defeat of the Swedish king Charles XII of Sweden by Peter the Great in the Battle of Poltava in 1709. The victory of the Russian army marked the demise of Swedish power as well as the beginning of the reign of Russia over the Baltic Sea. Over one hundred years later, the army of Tsar Alexander I drove Napoleon out of Russia and finally defeated him. The Russian army appeared on the streets of Paris, and as a result, Russia became the power which co-created the international order, sanctioned at the Congress of Vienna. In the 1940s, the Soviet Union was the winner of World War II. Soviet soldiers occupied Berlin and, after that, the empire was founded (together with satellite states) which played a key role in the shaping of the post-war order. Thus, it is not a surprise that the Russian authorities and Russian society could not come to terms with the loss of their superpower status after the demise of the USSR and - beginning with the mid-1990s - they strove to regain the position of an important global player. It should be emphasised that it was a long and slow process, it can even be described as 
diffident, but the diffidence stemmed from the difficult political and economic situation of the USSR's successor. When Moscow paid back its liabilities to the international financial institutions, it started to express its national interests more forcefully. Such practice by the Kremlin is perfectly explained by Roman Backer who rightly notices that no matter if it is a utopian dream of returning to superpower status or a more realistic strive to be one of the great players in the multipolar world, the imperial way of thinking is common in Russia (Backer 2007, p. 288).

\section{Russian Feeling of Uniqueness}

A vivid signal of a shift in Russian foreign policy appeared at a security conference in Munich in 2007, when Putin clearly defined Russian interests and firmly stated that he accepted neither being preached at by the West nor by the unipolar world. The world is multipolar and Russia has its own interests in it, which must be taken into consideration.

In this approach, reference is made to the concepts of Alexander Dugin, which enjoy the support of the Russian authorities. In his opinion, arguments of a historical, geographical, cultural or political nature indicate the superpower status of Russia.

One of the factors determining such assertive stance of the Russian leader is the conviction that Russian power is, to a much extent, determined by its territorial potential. The Russian Federation, which constitutes 10\% of the surface of the globe, is convinced that it should have an influence on the situation in Europe, Asia, the Arctic, the Pacific and the Middle East. The territorial vastness reinforces Russia's belief that it is stronger than the United States.

The president of Russia also emphasises the civilisational uniqueness of his country, which can also be proved by the fact there are over one hundred different nationalities living on the territory of the RF. When Russia holds talks with the European Union, it presents itself as a European country, but during talks with, for example, China it is Asian. Such a feeling of uniqueness makes its mark on the activities of offensive and defensive character. On the one hand, it gives Russia a quasi-moral right to become engaged in all world affairs, all the more as it is a member of every important international organisation. On the other hand, it does not allow foreign ideologies to be adopted, including western democratic liberalism. 
It seems that when Putin talks about Russia’s specificity, special situation and tradition, he means geographical legitimisation (Torbakov 2011). Geography exerts an important influence on the political and strategic culture. Russia boasts that on its territory, 'the whole Periodic Table' can be found. Such a situation not only determines the economic development and strengthens the feeling of its own power, but ialso builds relations with many other countries. Although for the West, and recently also for China, Russia is most of all a state with natural resources, according to Russia, is status of owner of the natural resources legitimates its uniqueness and power (Lo 2015, p. 42).

Russian self-definition is also influenced by a demographic factor. On the east side of the Urals, there are only 30 million citizens, which means that over 100 million people living west of the Ural Mountains feel that they are Europeans, looking with admiration - in spite of the propaganda - at the West. It is proved by the character of the political structures and their functioning, the perception of economic processes, social and cultural norms, as well as self-identification. Even at a time of worsening relations with the West, during the Cold War and presently, these Russians would like to live, study, and invest in Western Europe and the United States.

\section{Radical Turn in Russian Foreign and Security Policy}

The assertiveness of Russian policy was slightly weakened during Medvedev's presidency, but Putin's next term of office, which began in 2012, is notable not so much for the return to the phraseology from the time of his second term of office, but rather by a radical twist. The Kremlin circle of power concluded that it was time to turn Russia into one of the centres of the multipolar world. There were several reasons for the change.

The first reason was the belief that the distribution of power in the contemporary world had changed. The West, which aspired to a leadership role, the creator of a perfect political and economic system, found itself in trouble. This was proven, inter alia, by the financial crisis which began in 2008 and the economic problems faced by the countries of the Euro zone, which evoked disintegration tendencies dormant in some EU countries. The financial crisis in Greece constituted a strong basis for speculation that not only the Euro zone was in crisis but the whole EU. It was estimated that the 
world centres of power were moving to the east, but at the same time the importance of BRICS $^{3}$ as the new centre of the world economy was overestimated.

The second reason was the growing Russian confidence about its economic autonomy and independence. This was the result of almost complete control over the internal market by Russian resource monopolies and reducing foreign entities to a secondary role. Russian concerns wanted to be dominant not only in the post-soviet region, but also in the West. This resulted from the intervention of the state into contracts concerning the terms of the exploitation of the Russian deposits by western concerns. They were accused of not conforming to ecological norms, visa procedures for specialists were blocked, and the police carried out searches (The Guardian 2008). As a result, a forced sale of foreign shares to Russian economic entities took place. One of the most spectacular examples in this respect is the total takeover of the Russian-British company TNK-BP by Rosnief in 2012. After the takeover of TNK-BP, Rosnief became the largest oil concern in the world in the hands of a state (the Russian State Treasury owns about $75 \%$ of its shares), extracting about 4 million barrels of oil a day, which constitutes about $1 / 3$ of the overall extraction in Russia (Rosnieft przejmuje w catości... 2012).

The third reason was an optimistic assessment of the integration processes which were supposed to be progressing successfully in the post-soviet sphere, and the countries located in the area were effectively attracted by Russia to join international institutions where Russia was the driving force and a leader. These included the Commonwealth of Independent States (CIS), the Eurasian Customs Union (EACU), the Collective Security Treaty Organisation (CSTO), as well as the Union State of Russia and Belarus. Cooperation in the framework of those organisations formed the basis for the establishment of the Eurasian Economic Union (EAEU), which took place in May 2014. At the beginning, it consisted of Russia, Kazakhstan, and Belarus, and by the end of 2014, it was enlarged by Armenia and Kyrgyzstan.

Fourthly, Russian politicians were very disappointed with Medvedev's foreign policy. The support for his presidency resulted from the assumption that entrusting a representative of the younger generation, without a past in the KGB, with the top office in the state would bring about good relations with the West on terms acceptable for Russia (Trienin 2015, pp. 4-7). At the beginning, there was every indication that the situation would

3 A group of emerging national economies: Brazil, Russia, India, China, and the Republic of South Africa. 
develop in this direction. The West relatively quickly forgave Russia for the incursion into South Ossetia and Georgia by the Russian army during a conflict with this state in August 2008. Relations returned to normal, and there was the so-called reset in RussianAmerican relations. In 2010, the START (Strategic Arms Reduction Treaty) was signed as well as the Partnership for Modernisation. However, despite those achievements, there was a common belief in Russia that the West had failed to grant Russia its proper, prominent place in the decision-making system in matters of international security and other global issues. The Russian power elite's belief in this respect was confirmed by the Arab Spring and its consequences in the period of 2011-2012. Moscow interpreted the activities of the USA and the West, supporting the subversion of regimes, as meddling into affairs in regions close to Russia in terms of geography, politics and history. The ousting of Gaddafi and his humiliating death, as well as further development of the situation in Libya made a strong impression on Moscow. Higher ranking state officials and politicians believed that the actions of the West without asking for Russia's opinion proved not only that Russia was ignored as a super power, but also affected Russia's vital interests, which were connected with obtaining, in the eyes of the Arab world, the status of a credible and effective power capable of conducting an independent international policy. They took into account the possibility of creating a bloc of states able to oppose American politics in the Middle East. The last aspect was to obtain, for instance through arms contracts, a permanent instrument for influencing the foreign and domestic policy of these countries.

Fifthly, it was assumed that public demonstrations against the authorities during the Duma elections in 2011 and presidential elections in 2012 were inspired, directed and financed by the West, and in particular by the USA. The protests took place in Moscow, Saint Petersburg and in many other big cities. The Kremlin concluded that the participation of non-governmental organisations, financed by western countries, in the protests was one big non-informative operation of American secret services. Public demonstrations were quickly quelled, but they made a powerful impression on the authorities who were afraid of the dismantling of the existing political system. The events had a vital impact on foreign policy. They strengthened the anti-western beliefs of the governing elite which were spread to Russian society through state-controlled propaganda.

It was not the first time that the representatives of the Russian authorities assumed that the American secret services stood behind non-informative operations in this respect. The same assumptions were made during the so-called orange revolution in Ukraine 
in 2004 and other colour revolutions in the states of the CIS region. It is important to be aware that Russia cares a lot about the stability of its political system as well as the systems of CIS states. This is where the presumption stems from that the colour revolutions are one of the most serious threats to this stabilisation. Such movements are perceived - contrary to the assessment of the West - not as the awakening of civic societies demanding democracy in the western style, but as coups. The opposition forces, with the help of western states and their secret services, simply want to overthrow legitimate governments and impose a political culture foreign to these societies. The Russian leader openly states that he does not accept any interference into these states' affairs, emphasising with hypocrisy that they have the right to sovereignty (Putin Tells UN... 2015), forgetting that he himself violated the sovereignty of Ukraine in 2014. Combating colour revolutions is one of the challenges which are translated into the tasks for the armed forces, which is reflected in the Military Doctrine of the Russian Federation of 2014 (Wojennaja doktrina 2014).

Coming back to the main idea, Russia has never accepted the unipolar international order which emerged after the breakup of the cold-war world. If it accepted and applied tips and advice from the West, it was the result of its weakness. It tried to resist ineffectively, but the resistance was only symbolic. Deploying commandoes from Bosnia to Kosovo at the time of conflict in this province did not dispose the West to change its course of action and the peace mission was continued. Protesting with France and Germany against the war in Iraq in 2003 did not prevent the US operation in the country, although there was no United Nations Security Council resolution clearly accepting the use of force. Putin's speech in Munich, mentioned earlier, was a clear declaration that Russia would not accept the rules of conduct in international relations if they were established without its participation and agreement. War operations in Georgia were to show that the Kremlin's attitude was invariant and Russia would not hesitate to use force to adhere to its beliefs and rules.

\section{Characteristics of Russian Foreign and Security Policy}

After the presidential elections in 2012, Russian foreign policy totally changed. The changes are of qualitative character, which allows them to be classified as a new era in Russian foreign policy. It is proved by some vital traits which can be noticed with 
ease. What is especially worth noting is the change of attitude towards the standards of international law. As a response to new, non-treaty tasks of the North Atlantic Alliance - the NATO operation in Kosovo, the war in Iraq in 2003 - Russia strongly emphasised that the West was breaching the standards. It was a priority of Russian politics - at least in the diplomatic rhetoric - which seemed to be unalterable. In accordance with those principles, no other entity but the UN Security Council has the right to make decisions on the use of force. After the annexation of the Crimea, the diplomatic language changed into a new form of narration, which cnotes the objectively existing moral standards. In accordance with this line of thinking, Russia had the right to defend the human rights and interests of the citizens of the Crimea of Russian nationality (Wstriecza s czlenami Sowieta... 2014). In this case, international law took up an ideological formula. In the era of Yeltsin and Putin, until 2008, as well as of Medvedev, what was emphasised was the pragmatism of Russian foreign policy.

Taking office in 2012, Putin not only stressed the necessity to make Russia one of the centres of the multilateral global order, but without any restraints he also began to articulate the need for a radical change of the rules of conduct in the international environment. Russia does not only want changes which it would find satisfactory. It also advocates the creation of new international institutions which would replace the existing ones, dominated by the USA and their allies. It seems that the present conflict between Russia and the West concerns not only the expansion of influence in the classical meaning, but the conflict among international organisations.

In the Russian power circles in the 1990s, the ideas ofor signing an international treaty appeared, with the aim of sanctioning the state of affairs which emerged after the end of the Cold War. In this context, there is a view that the lack of such a document is nowadays a source of many conflicts and tensions. This was expressed, inter alia, by Yevgeny Primakov who, in an extensive analysis of Russia's place in the world after the end of the Cold War, advised the re-establishment of the international order in the formula of the new Yalta, with a clear division of the spheres of influence of Russia and the West (Primakov 2009). If such a solution was adopted, it would mean creating a kind of impassable red line along the border of the former USSR. But things developed differently. The Americans, who for forty years were afraid of the Soviet Union, now decided that it lost the Cold War and it should, in their opinion, pay for that. The West told Russia that it had lost the status of a superpower and, thus, it should behave in accordance with recommendations from the West. This caused Russian politicians to 
protest and the whole society felt deeply humiliated. The evident proof of the latter was the bombardment of Yugoslavia.

Since Munich, the Russian authorities consistently maintained the then presented view concerning the place of Russia in international relations. This point of view was repeated by Vladimir Putin in October 2014 at the meeting of the Valdai Discussion Club ${ }^{4}$ : 'The Cold War had ended but not by signing any peace treaty which would clearly determine the observance of the existing rules or the creation of new rules and standards. Such a situation creates an impression that the so-called winners of the Cold War have decided to influence events and are changing the world to serve their own needs and interests. When the existing system of international relations, international law and balance becomes an obstacle on their way, the system is deemed worthless, obsolete and requiring immediate overthrowing' (Meeting of the Valdai International... 2014).

Although it is officially stated in Russia that the multipolar system is the ideal model, in fact it is about returning to a quasi-bipolar world, where only Russia and the United States count, and other states are a little lower in the international hierarchy. The Americans receive such signals at almost every occasion. In greetings sent to Obama on the national holiday in July 2015, Putin expressed his hope that the two countries could tackle the most complex international problems, effectively counteract global threats and challenges, observing the rules of equality and mutual respect for their interests (Congratulations to US President... 2015).

Russia realises that it is far behind the USA in terms of the economy. Russia's economy constitutes only $1.5 \%$ of the global GDP and one fifteenth of the US economic potential. What is more, taking into consideration the development based on the sale of raw materials, mostly fuel, the constant dynamics and technological achievements of the USA, the fast growing power of China and India, one can assume that the chances of catching up with the West and obtaining the status of a superpower are small. Therefore, Russia decided that its status should be ensured by the armed forces being capable of reacting rapidly in every corner of the world. This can be attained, inter alia, by programmes of modernisation of the Russian Armed Forces, multiple military training

4 Valdai International Discussion Club is an annually organised meeting of experts during which the problems of Russian policy are discussed. The Club was created in 2004 at the initiative of several Russian magazines and the Russian Council on foreign and defence policy. The name comes from the first meeting which took place in Veliky Novgorod near Lake Valdai. 
courses run independently or as part of the Collective Security Treaty Organisation (CSTO), and Shanghai Cooperation Organisation (SCO).

One of the most important training undertakings in 2016 was the Strategic Commandand-Staff exercise 'Caucasus-2016', which was mostly held in the region of the Southern Military District from 5-11 September. Parts of the exercise were carried out on four training grounds: Prudboy in Volgograd Province; Kapustin Yar - spaceport and rocket military training ground in the north-west part of Astrakhan Oblast; Ashuluk in Astrakhan Oblast near the Kazakh border; Opuk near Theodosia in the Crimea - as well as on the Black and the Caspian Sea. It involved the participation of about 120 thousand people (at different stages). About 12 thousand soldiers trained in the Southern Military District. During the exercise, brigade groupings were supported by aviation forces, air defence, maritime forces, missile troops and artillery.

The largest exercises were held on the training grounds of the Southern MD, Central $\mathrm{MD}$, and the Northern Fleet. Subunits of territorial defence were formed. They included 700 soldiers of the reserve called up for military service from the Oblasts of Rostov, Novosibirsk, Arkhangelsk, and Murmansk. This way they carried out an experiment concerning the new system of operational readiness and mobilisation of the reserve forces for territorial defence. The special forces and land forces taking part in the experiment used the experience gained during the Russian campaign in Syria. In the training area of the Black Sea Fleet (Opuk), a hypothetical enemy, supported by aviation, carried out a landing of five assault groups from five landing ships. Prior to that, the enemy carried out engineering reconnaissance of the elements of the Russian defence and performed sabotage actions. The defence responded with strikes from the missile systems: Bal, Bastion, BM-21 'Grad', and BM-27 'Uragan' of tube artillery squadrons equipped with $152 \mathrm{~mm}$ gun-howitzer Msta-B, and Msta-S, as well as $122 \mathrm{~mm}$ self-propelled howitzer 'Gvozdika'. Strikes on the landing groups of the enemy were also launched by the aircraft of the operational-tactical aviation. Communications were destroyed by the Khibiny radio-electronic countermeasures system installed on the deck of two fighters SU 27. The task of Ka-52 'Alligator' and MI-28H 'Night Hunter' helicopters was to destroy the attacking subunits as well as sea targets. The air targets were shot down by the fourthgeneration surface-to-air missile systems S-400 'Triumf'. As a result, the defence forces managed to take over the initiative. Supported by aviation, the second echelon brigades joined the fight, and after reaching the line of the attack, destroyed the landing forces of 
the enemy and took defence positions along the coastline (Zavolokin and Khudoleyev, 2016).

Although Russia wants to demonstrate its military potential and operational readiness, as well as capability of fast reaction, not everything is ideal. According to Ukrainian intelligence, it was possible to observe many problems and mistakes during the manoeuvres. On the day when the exercise commenced, only one out of five artillery squadrons was partly prepared to perform the combat tasks on the Pruboy range. Among other things, the following were not prepared: the squadrons of the 291st artillery brigade of the 58th army (Vladikavkaz); the squadrons of the 244th artillery brigade from Kaliningrad (Northern Military District), as well as the squadrons of the 385th brigade of the 2nd army of the Central Military District (Rzeczywisty stan... 2016).

Ukrainian intelligence claims that the naval forces, including the Baltic Fleet (BF), also face problems. The audit carried out in May and June revealed certain negligence in terms of operational readiness of battleships and the poor technical condition of auxiliary ships. They also noticed the poor lodging conditions for soldiers as, inter alia, seventy officers' families lived in wrecked buildings without hot water. As a result, the minister of defence, Sergei Shoygu, dismissed the commander of the BF, Vice-Admiral Viktor Kravchuk and the Chief of Staff, Admiral Sergei Popov (Wielka czystka we Flocie... 2016). The purge also entailed over fifty high-ranking officers of the fleet's staff, commanders of squadrons, brigades and military units (Po aferze dymisje... 2016). ViceAdmiral Aleksandr Nosatov was appointed the acting commander of the Baltic Fleet (Wiceadmirat Nosatow... 2016).

At the same time, it can be seen that Russian security policy is strongly militarizsed. In the Military Doctrine of 2014, there is a strong emphasis on the importance of the armed forces in achieving the goals of foreign policy. Among the core external threats, the expansion of NATO's military potential and the approaching of its military infrastructure to the RF borders through the enlargement of the Alliance and the allocation of military contingents in states that have friendly relations with Russia and waters bordering it were identified. The aim of such conduct is to exert political and military pressure (Wojennaja doktrina 2014, art 12 a, b, w). The doctrine includes a point 25 which is symmetric to Article 5 of the Washington Treaty, and reads: 'The Russian Federation considers a military assault on any state - member of the CSTO as aggression against all states of the CSTO and in such a case it will take action in accordance with the Collective Security Treaty (Wojennaja doktrina 2014, art 25). 
In 2013, the Special Operation Forces were established. They will perform tasks on the territory of Russia and abroad. In this case, as in many other cases, Russia's inferiority complex with regard to the United States shows. One of many justifications for the establishment of the forces involves a statement that such a formation has existed in the USA for over 40 years (Bował 2013). It was also decided that one of the best formations of this type in the world - GRU's Spetsnaz - iwas not enough to fulfil all tasks. The assumption turned out to be prophetic during the annexation of the Crimea, when subunits of special forces without any badges performed military and non-military tasks. The militarisation of foreign policy is also revealed by the reservation of the right to use nuclear weapons in a conventional conflict if Russia considers that the existence of the state is endangered (Wojennaja doktrina 2014, art 27).

In 2015, Russia totally withdrew from the Treaty on Conventional Armed Forces in Europe, claiming that it was a response to the enlargement of NATO's potential and the escalation of exercises close to the border of the RF (Arlak 2015). Russian experts also advised that Russia should withdraw from the Treaty on Intermediate-Range Nuclear Forces of 1987 (Khudoley 2016, p. 395). In October 2016, Putin decided to withdraw from the agreement on reprocessing of old stores of plutonium, which could be used for military purposes, reasoning that the United States did not comply with the agreement.

\section{Conclusions}

Nobody negates the fact that Russia is still one of the largest countries in the world. Nonetheless, it is much smaller and weaker than the USSR. By means of assertive, not to say aggressive, anti-western politics it demands to be recognised as a superpower eligible to decide on the international order. However, in the contemporary world, a territory decides about its superpower status to a much smaller extent. What counts more is the dynamics of the economic development, the application of advanced technology, and the use of human resources. Russia's domestic problems, one of the most important being the growing political radicalism of the followers of Islam, are also significant. This problem will not be easy to tackle since $15 \%$ of 142 million Russian citizens are Muslim. Thus, the foundations of the Russian superpower status are weak, and the popular anti-western narrative is not conducive to strengthening the Kremlin's position internationally. 


\section{References}

Arlak, S. 2015. Rosja catkowicie wycofata się z Traktatu o Konwencjonalnych Sitach Zbrojnych $w$ Europie [online]. Polska Times. Available from: http://www.polskatimes.pl/ artykul/3781441, rosja-calkowicie-wycofala-sie-z-traktatu-o-konwencjonalnych-silachzbrojnych-w-europie,id,t.html [Accessed 14 Oct 2014].

Backer, R. 2007. Rosyjskie myślenie polityczne za czasów prezydenta Putina [Russian political thinking during President Putin's time, Toruń: Adam Marszałek.

Battle for TNK-BP turns into all-out war. 2008. [online]. The Guardian. Available from: https:// www.theguardian.com/business/2008/jul/27/bp.oil [Accessed 9 Oct 2016].

Bował, W. 2013. Sity Spiecyalnych Opieracyj w Rossii gotowy k primienieniju. [online]. Wojennoje obozrienije. Available from: https://topwar.ru/26966-sily-specialnyh-operaciy-v-rossiigotovy-k-primeneniyu.html [Accessed 14 Oct 2016].

Congratulations to US President Barack Obama on Independence Day, 2015. [online]. Available from: http://en.kremlin.ru/events/president/news/49864 [Accessed 12 Oct 2016].

European Union. Living in the EU [online]. Available from: https:/europa.eu/european-union/ about-eu/figures/living_en [Accessed 2 October 2016].

Gertz, B., and Scarborough, R. 2002. GRU chief visits. Washington Times, 15 February.

Khudoley, K.K. 2016. Russia’s foreign policy amid current international tensions. Teorija in praksa (2), 288-408.

Kotkin, S. 2016. Russia’s Perpetual Geopolitics: Putin Returns to the Historical Pattern. Foreign Affairs, 95(2).

Lo, B. 2015. Russia and the New World Order. Washington: Brookings Institution Press.

Lyman Miller A. 2005. China an Emerging Superpower? Stanford Journal of International Relations. [online]. Available from: https://web.stanford.edu/group/sjir/6.1.03_miller.html [Accessed 15 March 2019].

Meeting of the Valdai International Discussion Club. 2014. [online]. Available from: http:// en.kremlin.ru/events/president/transcripts/46860 [Accessed 25 Oct 2014].

Mleczin, L. 2011. Ministry inostrannych diet. Tajnaja diptomatija Kriemla. Wnieszniaja politika Rossii: ot Lenina i Trockogo do Putina i Miedwiediewa. Centrpoligraf, Moskwa.

Orłow, D. 2006. Byt' li Rossii „eniergieticzeskoj swierchdierżawoj”? [online]. Izwiestija. Available from: http://izvestia.ru/news/310285 [Accessed 8 Oct 2016].

Po aferze dymisje we Flocie Battyckiej. Dowódca tymczasowy, gietda nazwisk. 2016. [online]. TVN24.pl. Available from: http://www.tvn24.pl/wiadomosci-ze-swiata,2/rosja-flotabaltycka-dowodca,657395.html [Accessed 14 Oct 2016].

Primakow, J., 2009. Mir biez Rossii? K czemu wiediet politiczeskaja blizorukost'. Rossijskaja gazieta

Putin Tells UN: National Sovereignty Needs to Be Respected. 2015. [online]. Sputnik. Available from: https://sputniknews.com/analysis/201509291027693872/ [Accessed 12 Oct 2016].

Rosnieft przejmuje w catości spótkę TNK-BP, 2012. [online]. Centrum Informacji o Rynku Energii. Available from: http://www.cire.pl/item,66959,1,0,0,0,0,0,rosnieft-przejmuje-w-caloscispolke-tnk-bp.html [Accessed 9 Oct 2016]. 
Rzeczywistystan wojsk rosyjskich. Wywiad o kulisach ćwiczeń Kaukaz. 2016 [online]. TVN24.pl. Available from: http://www.tvn24.pl/wiadomosci-ze-swiata,2/rosja-cwiczenia-kaukaz-2016,674119.html [Accessed 14 Oct 2016].

Speech at ceremony opening ARMY-2015, 2015 [online] Available from: http://en.kremlin.ru/ events/president/transcripts/49712 [Accessed 8 Oct 2016].

Torbakov, I. 2011. What Does Russia Want? Investigating the Interrelationship between Moscow's Domestic and Foreign Policy. DGA Panalyse [online], (1). Available from: https:// dgap.org/de/article/getFullPDF/17753 [Accessed 8 Oct 2016].

Trienin, D. 2015. Rossija porwata s odnopolarnoj sistiemoj: pobuditielnyje motiwy politiki Putina [online]. Carnegie Endowment for International Peace. Available from: http:// carnegieendowment.org/files/CP_Trenin_Rus_Web2015.pdf [Accessed 10 May 2017].

Wiceadmirat Nosatow naznaczen komandujuszczim Battijskim ftotom. 2016. [online]. Available from: http://tass.ru/armiya-i-opk/3645483 [Accessed 14 Oct 2016].

Wielka czystka we Flocie Battyckiej. 2016. [online]. Kresy.pl. Available from: http://www.kresy.pl/ wydarzenia,bezpieczenstwo-i-obrona?zobacz/wielka-czystka-we-flocie-baltyckiej] [Accessed 14 Oct 2016].

The World Factbook. 2016a. [online]. Available from: http:/www.theodora.com/wfbcurrent/ russia/russia_geography.html [Accessed 8 Oct 2016].

The World Factbook. 2016b. [online]. Available from: http://www.theodora.com/wfbcurrent/ russia/russia_geography.html [Accessed 8 Oct 2016].

Wojennaja doktrina Rossijskoj Fiedieracyi. 2014. [online]. Available from: http://kremlin.ru/ events/president/news/47334 [Accessed 12 Oct 2015].

Wstriecza s czlenami Sowieta pataty Sowieta Fiedieracyi. 2014. [online]. Available from: http:// www.kremlin.ru/events/president/news/20645 [Accessed 12 Oct 2016].

Zavolokin, P., and Khudoleyev, V. 2016. Tawrida - ariena uczebnogo boja. SKSZU „Kawkaz-2016” stało ważniejszym mieroprijatijem bojewoj uczoby w etom godu. Krasnaja Zwiezda, 12 September.

Zygar, M. 2016. Wsia kriemlewskaja rat'. Kratkaja istorija sowriemiennoj Rossii., Moscow: Alpina Digital.

\section{Authors:}

Mirosław Minkina, PhD, Assoc. Prof.

Siedlce University of Natural Sciences and Humanities, Faculty of Humanities, Siedlce, Poland (iD) https://orcid.org/0000-0002-2391-314X 